Asian-Australasian Journal of

Food Safety and Security

ISSN 2523-1073 (Print) 2523-2983 (Online)

www.ebupress.com/journal/aajfss

\title{
Article \\ Women's empowerment through small-scale dairy farming in Bangladesh: a study on some selected areas of Mymensingh district
}

\author{
M. Rafiqul Islam ${ }^{1}$, S. M. Lutful Kabir ${ }^{1 *}$ and Md. Serazul Islam² \\ ${ }^{1}$ Department of Microbiology and Hygiene, Bangladesh Agricultural University, Mymensingh-2202, \\ Bangladesh \\ ${ }^{2}$ School of Business, Bangladesh Open University, Gazipur-1705, Bangladesh
}

*Corresponding author: Professor Dr. S. M. Lutful Kabir, Department of Microbiology and Hygiene, Bangladesh Agricultural University, Mymensingh-2202, Bangladesh. Phone: +8801754987218; E-mail: lkabir79@bau.edu.bd

Received: 31 October 2019/Accepted: 24 November 2019/ Published: 30 November 2019

\begin{abstract}
The study was designed to explore the women's empowerment through small-scale dairy farming in Bangladesh. Small-scale dairy farm owners constituted the population of the present study. Among the population, the households who were actively engaged in dairy farming activities more than one year in the selected area of Mymensingh district, they were considered as the sample unit. For data collection, 50 households from the sample unit were randomly selected for interview. Simple percentages were calculated to show the frequency distribution at different categories of variables. Through small-scale dairy farming, rural women were able to increase their confidence and decision-making power with regard to their household and personal care and experienced increased self-esteem, expansion of their social circles, and ultimately enhanced empowerment through the breakdown of traditional socio-cultural norms. Thus, the expansion of small-scale dairy farming in other rural areas of Bangladesh is likely to contribute to the empowerment of more rural women.
\end{abstract}

Keywords: small-scale dairy farming; women's empowerment

\section{Introduction}

Women's empowerment plays an important role in socio-economic development in any country that involves improving decision-making, control over income, awareness about personal rights and freedom, improving position in the family and in general the confidence of rural women in their capabilities. Keller and Mbwewe (1991) stated that Empowerment is a process whereby women become able to organize themselves to increase their own self-reliance, to assert their independent right to make choices and to control resources which will assist in challenging and eliminating their own subordination. Self-reliance, choices, control over resources. Women's empowerment is all about equipping and allowing women to make life-determining decisions through the different problems in society (Bayeh, 2016).

Bangladesh has been a role model in women's empowerment in the past decade, and the country is experiencing an appreciable change in society because of its efforts in this regard. The concept of women's empowerment and efforts in this area has helped the country attain a steady progress in gender equality, which helped Bangladesh to secure the first spot in gender equality (among South Asian countries) for the second consecutive year at the Gender Gap Index (GGI) of 2017. The index, prepared by World Economic Forum (WEF), measures education, economic participation, health and political empowerment to measure gender equality of any country. Half of the population of Bangladesh is women and their economic participation has increased significantly. The UNDP has commented that "Bangladesh has made significant progress in promoting the objectives of ensuring gender equality and empowerment of women". Rural women have been 
deprived of their rights in the family from early childhood. Most of the women in rural areas must bear the double burden of domestic work and dairy farming. The major activities related to dairy farming are normally performed by rural women in Bangladesh. Due to the patriarchal system of the society, their hard work and their contribution to household expenditure have been undervalued, and they do not receive proper respect for their work.

Siddique (1998) stated that women receive less household resources for their food, education, health and clothing than men. Hashemi and Schuler (1993) identified a number of domains in which women have traditionally been stripped of autonomy, such as physical mobility, financial security, and freedom in social interactions.

Batliwala (1994) highlighted, women's empowerment must encompass a direct challenge of institutions of power (e.g. family, media) and power structures (e.g. Legal, economic) toward the goal of gaining autonomy. Women's empowerment may also be generally defined as an ongoing process where in a woman acquires the ability to define and successfully pursue personal objectives (Kabeer, 1999). Aggression against women within the family is considered as breaking the rules or affecting their self-esteem (Kamal, 1995). Smallholder dairy production is becoming increasingly important and it contributes magnificently to the improvement of the livelihoods of rural people. Smallholder dairy production was found to be an important and have the potential to poverty alleviation, food security, improved family nutrition and income and employment generation (Uddin et al. 2012). Farming has enabled them to increase family income as well as fulfill household food needs (Batool $e t$ al., 2014).

Through their participation in income generating activities like small-scale dairy farming, rural women are able to transcend traditional barriers and have the potential to escape oppression such as domestic violence that limits their empowerment. Small-scale dairy operations run by rural women are growing increasingly popular in Bangladesh due to the limited costs of rearing dairy animals on personal homesteads. Currently, small-scale dairy farming is considered one of the best ways for these rural women to utilize their limited resources and to develop skills that will contribute to their empowerment. Small-scale dairy farming systems are significantly expanding in the selected areas of Mymensingh district due to development of more awareness to increase family income, socio-economic status and thus enhance the livelihood. Thus, the expansion of small-scale dairy farming in other rural areas of Bangladesh is likely to contribute to the empowerment of more rural women.

In the course of small-scale dairy farming, rural women were able to increase their confidence level through improving educational, nutritional and legal right awareness and health consciousness and decisionmaking power with regard to their household and personal care and experienced, and freedom of mobility, increased self-esteem and self-respect, expansion of their social circles, and ultimately enhanced empowerment through the breakdown of traditional socio-cultural norms and reduction of dependency.

\section{Materials and Methods}

\subsection{Research design}

The study was descriptive in nature. According to Oso and Onen (2005), descriptive study was involved enquiring the different kinds of fact findings which helped to draw the conclusion about targeted population by describing the data.

\subsection{Types and sources of data}

Primary and secondary, both types of data were used to carry out the study. The primary data were collected from rural women who possessed the small-scale dairy farm in selected area. The secondary data were collected from the articles of different journals, books, magazines, newspapers, annual reports, website, unpublished $\mathrm{PhD}$ theses, research reports, and other publications related to the present study.

\subsection{Population of the study}

To conduct the study meaningfully adequate care was taken in selecting the households who were engaged in dairy farming activities at Digharkanda in Mymensingh District of Bangladesh. Small-scale dairy farm owners in selected area were constituted the population of the study.

\subsection{Sampling unit of the study}

Among the population, the households who were actively engaged in dairy farming activities more than one year in the selected area of Mymensingh district, they were considered as the sample unit of the study. 


\subsection{Sampling technique}

Probability Sampling Method (PSM) also known as Random Sampling Method (RSM) was applied to carry out the study.

\subsection{Sample size}

The women in the study area who are engaged in dairy farming activities, 50 (Fifty) households were interviewed in total from the sampling unit. The quantitative and qualitative nature of the research influenced the choice of sample size in terms of the selected rural women, based on the population profile rather than the number of people.

\subsection{Data collection procedure}

The observation, questionnaire, and telephonic interview methods were used to collect primary data from the selected rural women. With the help of interview schedule consisting of several types of question, face to face interview with the selected woman was conducted to collect data. After extensive related literature review the interview schedule and questionnaire will finally be designed according to research expert opinion and prospective respondent's views to the extent possible. Secondary data will be amassed by desk research by using different books, journals, articles, magazines, newspapers, annual reports, website, and other publications.

\subsection{Instrument design}

Before the final data collection stage was started, the interview schedule and the questionnaire were carefully studied and moderated. To increase validity and reliability, a pilot survey was also conducted to pre-test the questionnaire. Before finalization of the interview schedule and questionnaire, in the study, a pilot survey was conducted with the objective of ascertaining the workability and face validity of the questions. In view of these objectives, a total of 5 selected rural women were purposively selected for the pilot survey. Some questions particularly multiple choice questions were amended by adding or discarding. The questions not so relevant for achieving objectives of the study were also excluded from the list of questions. Based on the experience of the pilot survey, the approach of asking question, contact time, the recording, processing and reporting of data were finalized with amendment. The respondents were selected for the pilot survey, however, who were not finally included in the sample of woman respondents.

\subsection{Data processing and analysis}

The task of processing consisted of editing, coding, classification, and tabulation of collected data so that they were amenable to analysis. At the end of each day of data collection, the collected raw data were verified to ensure that the selected rural women answered all relevant questions and that no answers were missing. The completed interview schedule was carefully scrutinized to assume that the data were accurate, consistent with other facts gathered uniformly entered, as complete as possible and had been well arranged to facilitate coding and tabulation. The values of the variables were coded by numerical figures and the numerical coded numbers were given input for analysis of the data. Then the data were tabulated and analyzed with the help of computer. After completion of field study, data were inserted in computer based worksheets and MS Word. In this study descriptive statistics was used to present quantitative descriptions in a manageable form. Simple percentages were calculated to show the frequency distribution at different categories of variables.

\section{Results and Discussion}

\subsection{Dimension and indicators of women's empowerment}

In this study, several empowerment dimensions such as social, economic, decision-making, legal and psychological with indicators have been used to measure the level of empowerment among women living and working on small-scale dairy farms in some selected areas of Mymensingh district in Bangladesh. Regarding the different empowerment indicators, the percent distributions of all women's responses are shown in Table 1.

Social empowerment is the process of accessing opportunities and resources in order to make personal choices. Poor rural women are socially empowered through freedom of mobility, involvement in family affairs and community level and involvement in microcredit program and this process served to remove social barriers and obstacles. Social empowerment among the women in before and during study was quantified by considering three indicators: freedom of mobility, involvement in family affairs and community level and involvement in microcredit program. As can be seen in Table 1, social empowerment was higher in during study period. 
Table 1. Distribution of indicators of women's empowerment before and during study.

\begin{tabular}{|c|c|c|c|c|c|c|}
\hline \multicolumn{2}{|c|}{ Women's empowerment } & \multirow{2}{*}{ Category } & \multicolumn{2}{|c|}{ Before study } & \multicolumn{2}{|c|}{ During study } \\
\hline Dimensions & Indicators & & Frequency & Percentage & Frequency & Percentage \\
\hline \multirow{8}{*}{ 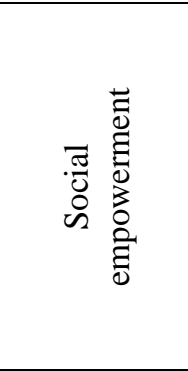 } & \multirow{2}{*}{ Freedom of mobility } & Yes & 6 & 12 & 38 & 76 \\
\hline & & No & 44 & 88 & 12 & 24 \\
\hline & \multirow{3}{*}{$\begin{array}{l}\text { Involvement in family } \\
\text { affairs and community level }\end{array}$} & Poor & 42 & 84 & 11 & 22 \\
\hline & & Moderate & 6 & 12 & 27 & 54 \\
\hline & & Good & 2 & 4 & 12 & 24 \\
\hline & \multirow{3}{*}{ Involvement in microcredit } & Poor & 32 & 64 & 8 & 16 \\
\hline & & Moderate & 12 & 24 & 27 & 54 \\
\hline & & High & 6 & 12 & 15 & 30 \\
\hline \multirow{7}{*}{ 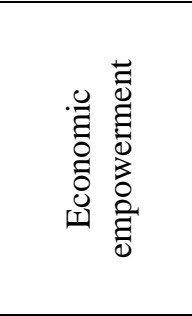 } & \multirow{3}{*}{ Income earning potential } & Poor & 40 & 80 & 4 & 8 \\
\hline & & Moderate & 6 & 2 & 24 & 48 \\
\hline & & High & 4 & 8 & 22 & 44 \\
\hline & \multirow{2}{*}{$\begin{array}{l}\text { Independence in spending } \\
\text { money }\end{array}$} & Yes & 4 & 8 & 42 & 84 \\
\hline & & No & 46 & 92 & 8 & 16 \\
\hline & \multirow{2}{*}{$\begin{array}{l}\text { Autonomy in financial } \\
\text { decision }\end{array}$} & Yes & 9 & 18 & 38 & 76 \\
\hline & & No & 41 & 82 & 12 & 24 \\
\hline \multirow{6}{*}{ 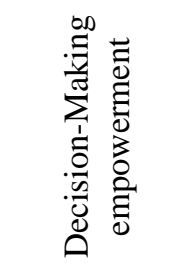 } & \multirow{2}{*}{$\begin{array}{l}\text { Take decision } \\
\text { independently }\end{array}$} & Yes & 6 & 12 & 31 & 62 \\
\hline & & No & 44 & 88 & 19 & 38 \\
\hline & \multirow{2}{*}{$\begin{array}{l}\text { Casting vote by own } \\
\text { initiative }\end{array}$} & Yes & 13 & 26 & 36 & 72 \\
\hline & & No & 37 & 74 & 14 & 28 \\
\hline & \multirow{2}{*}{$\begin{array}{l}\text { Involvement in major } \\
\text { household decision }\end{array}$} & Yes & 7 & 14 & 41 & 82 \\
\hline & & No & 43 & 86 & 9 & 18 \\
\hline \multirow{6}{*}{ 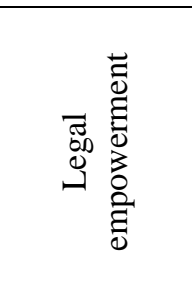 } & \multirow{3}{*}{$\begin{array}{l}\text { Awareness about gender } \\
\text { equity }\end{array}$} & Poor & 38 & 76 & 6 & 12 \\
\hline & & Moderate & 11 & 22 & 32 & 64 \\
\hline & & Good & 1 & 2 & 12 & 24 \\
\hline & \multirow{3}{*}{$\begin{array}{l}\text { Knowledge about property } \\
\text { and legal rights }\end{array}$} & Poor & 33 & 66 & 4 & 8 \\
\hline & & Moderate & 16 & 32 & 31 & 62 \\
\hline & & Good & 1 & 2 & 15 & 30 \\
\hline \multirow{6}{*}{ 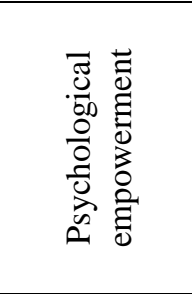 } & \multirow{3}{*}{ Self -respect } & Poor & 40 & 80 & 4 & 8 \\
\hline & & Moderate & 10 & 20 & 32 & 64 \\
\hline & & Good & 0 & 0 & 12 & 24 \\
\hline & \multirow{3}{*}{ Self-esteem } & Poor & 37 & 74 & 5 & 10 \\
\hline & & Moderate & 13 & 26 & 27 & 54 \\
\hline & & Good & 0 & 0 & 18 & 36 \\
\hline
\end{tabular}

Women exhibited greater freedom of mobility and were able to leave their home and visit the market, health care center, or the house of a neighbor or relative without permission from their husband or other elder members of the family. Farming helped the rural women to improve their socio-economic conditions and achieve sustainable development. According to Batool et al. (2014), small-scale dairy farming are considered a key means by which rural women can improve their family income by freedom of mobility. Following their involvement in dairy farming, the women were able to extend their social network and mobility. During study, majority percent (76) of respondent had freedom of mobility whereas 12 percent selected rural women had freedom of mobility before inclusion of small-scale dairy farming (Table 1).

Haque et al. (2011) used three dimensions to define women's empowerment index and found that economic and family decision-making authority is satisfactory while mobility is very low, and negative social views about female autonomy are still prevalent. Freedom of mobility increased the communication with other members. Increased communication with outside of their family, and develop further independence to involve in family affairs and community level. Before study, it was found that involvement in family affairs and community level was restricted. The study shown that 84,12 and 4 percent selected rural women have poor, moderate and good involvement in family affairs and community level respectively before study. On the other hand 22, 54 and 24 percent selected rural women have poor, moderate and good involvement in family affairs 
and community level respectively during the study (Table 1). The result stated that involvement in family affairs and community level were found significantly increased during study compared to before study.

Research evidence has previously demonstrated that microcredit programs can improve the productivity and development of income-generating activities (Alhassan, 2012), thus the women who take part in these programs they are more socially empowered than their peers who do not partake (Awojobi, 2014). Involvement in the microcredit program did expand the social network of women during study and enhance their social status and social recognition. Women participated in the microcredit program, where they can interact with other women and exchange knowledge, skills, and experiences. Islam et al. (2014) examined the impact of microcredit on women's empowerment in rural Bangladesh. Before study, women had moderate poor (64\%), Moderate (24\%) and good $(12 \%)$ involvement in microcredit program respectively. In contrast, during study, women had moderate (54\%) and good (30\%) involvement in microcredit program respectively that led to better social empowerment.

Sarah and Ikemoto (2015) stated that through participation in small-scale dairy farming rural women have been able to increase their consciousness and economic levels, and thereby making a significant contribution to the well-being of the family. Economic empowerment is another significant dimension of women's empowerment and the study has suggested that economic empowerment of women enhances through their participation in economic activities (Parveen and Chowdhury, 2009).

Rural women who involved in income-generating activities experience greater empowerment rather who are not engaged in any economic activity (Nessa et al., 2012). From the results gathered in this study, during the study, women earned much more money from dairy farming than before inclusion of small-scale dairy farming activities, due to their ability to provide adequate nutrition to dairy cattle and thereby improve farm productivity. During the study period, the selected rural women reported that they had poor (8\%), Moderate (48\%) and good (44\%) income earning potential by improving farm productivity but before the study they had poor $(80 \%)$, Moderate (12\%) and good (8\%) income earning potential respectively (Table 1).

Independence in spending money for family such as clothing, education or medicine is an important indicator for economic empowerment of rural women. The economic decisions the women make in dairy farming also foster independence with regard to making other expenditures for their family, on items such as clothing or medicine. Ahmed et al. (2011) revealed that rural women in Bangladesh have restricted access to incomeearning activities and less independence in spending money to contribute to the well-being of their families due to social, cultural and religious barriers.

84 percent selected rural women had independence in spending money for family. In contrast, before engaged in dairy farming activities only 8 percent respondent had independence in spending money for family (Table 1). This study reported that women in rural area secured high impendence in spending money to contribute to the well-being of their families.

Mujahid et al. (2015) highlighted the importance of economic and social equality for women's empowerment in Pakistan. Economic empowerment is fostered by decreases in poverty, access to credit programs, and lucrative work while social empowerment encompasses education, health care access, and other social opportunities. Only 18 percent women had autonomy in financial decisions before study. Whereas, 76 percent women had autonomy in financial decisions surrounding the care of their dairy cattle and exhibited remarkable economic success during the study (Table 1). This study reported that before engaged in small-scale dairy farming activities, women did not have more autonomy in financial decisions surrounding the care of their dairy cattle and did not exhibit the same economic success.

Decision-making plays a substantial role in corresponding quality of life for women. In patriarchal social system and upon marriage typically a woman is expected to obey all the rules mandated by her husband, is prohibited from making independent decisions, and has no right to challenge her husband's authority. During childhood, women are dependent on male family members and not educated or taught self-dependency.

Islam et al. (2012) also identified that homestead poultry rearing among rural women in Bangladesh promotes empowerment by encouraging independent decision-making and increased involvement in family affairs. Women were also allowed to make decisions regarding the health and general care of their children, such as choosing to vaccinate their newborns, making nutritious food choices, and opting to seek better treatment for their sick children. It is revealed from the Table 1 that only 12 percent women took decision independently before study. Moreover, 62 percent women took decision independently during the study. It is investigated that during the study, the women exhibited increased expression of personal preference and had the freedom to make good daily food and nutritional choices for their family and had similar authority in deciding how to feed their dairy cattle to improve productivity.

Casting vote by the selected rural women own initiative is very sensitive issues in rural area. Increasing the 
capacity of rural women is a necessary step toward allowing them equal right and power with men (Mulugeta and Amsalu, 2014). It is found that before involving with SDF, majority of women were influenced by others in the time of casting vote. 72 percent woman cast vote from their own initiative during the study period. While 26 percent woman cast vote by their initiative before study (Table 1).

The women were also involved in major family decision-making on issues related to family members, the marriage of a son or daughter, household repairs, and large purchases. Empowered women possess freedom for self-development and decision-making and equal access to domestic and community resources (Kumar et al., 2013). During study period, 82 percent selected rural women involved in major household decision-making on issues related to family members, the marriage of a son or daughter, household repairs, and large purchases. In contrast, before engaged in dairy farming activities only 14 percent selected rural women involved in major household decision-making (Table 1).

Since becoming involved with dairy farming, women are now more conscious of their legal rights. Through the process of earning money and using this income for family purchases, the women acquired bargaining skills and could express their differing opinions and disagree with their husband or other family members.

Sultana (2010) researched the socio cultural dimensions of women's inequity in rural society. In matters of marriage, divorce, maintenance and inheritance, women have traditionally been denied equal rights. Gender equity is the process of handing over resources, programs and decision-makings fairly to both males and females. Gender equity is the fairness of treatment for women and men, according to their respective needs. This may include equal treatment or treatment that is different but which is considered equivalent in terms of rights, benefits, obligations and opportunities. Gender equality and empowerment of women are vital to achieve sustainable improvement in the rural society (Afzal et al., 2009).

The increased decision-making power exhibited by the women in rural were considered as representative of significant progress toward the achievement of gender balance in their society. During the study period 12, 64 and 24 percent rural women were poor, moderate and good regarding awareness about gender equity respectively but before the study 76, 22 and 2 percent selected rural women reported poor, moderate and good regarding awareness about gender equity respectively (Table 1). This study identified that the women of the selected rural area were more aware of gender equity.

Banu et al. (2001) have shown that rural women, who involved in Bangladesh Rural Advancement Committee's Program, are able to acquire more knowledge of property rights and other legal right. Women were less conscious about their legal rights and powerless to seek them. During the study period 8, 62 and 30 percent women reported that they had poor, moderate and good knowledge about property and legal rights respectively but before the study 66, 22 and 2 percent women reported that they had poor, moderate and good knowledge about property and legal rights respectively (Table 1). This study exhibited that through small-scale dairy farming, women were more conscious about their property and legal rights compared to before inclusion of small-scale dairy farming.

Psychological empowerment is vital for the development of poor rural women in Bangladesh. The results revealed that women have experienced an increase in their confidence level and this has helped to enhance their efficiency and productivity in dairy farming.

Level of self-respect is another important indicator for psychological empowerment. Table 1 exhibits that majority percent (80) of selected rural women reported the level of self-respect were poor. Whereas, 64 and 24 percent selected rural women reported the level of self-respect were moderate and good during the study period. Comparison with women before and during study, women exhibited an increase in self-respect and enhanced status in their family after becoming involved with dairy farming.

Self-esteem can play a significant role in motivation and success throughout the life. Low self-esteem may hold back from succeeding work. Having a healthy self-esteem can help to achieve due to navigate life with a positive, assertive attitude and believe that can accomplish the goals. Maximum 74 percent selected rural women reported the level of self-esteem were poor before inclusion of small-scale dairy farming. Whereas, 54 and 36 percent selected rural women reported the level of self-respect were moderate and good during the study period (Table 1). Small-scale dairy farming activities had a great impact on self-esteem of selected rural women.

\subsection{Factors affecting the women's empowerment through small-scale dairy farming}

The variables that may affect women's empowerment through dairy farming are: types of dairy animal breed, the husband's behavior, breakdown of traditional socio-cultural norms, increase knowledge and skill and successful reduction of the dependency of rural women.

Types of breed were considered in this model as an important determinant for women empowerment in the selected area. Sarah and Ikemoto (2015) stated that rearing crossbred rural women earned more money due to 
their high productivity had a significant contribution to the well-being of the family. The majority of the selected rural women (62\%) reared crossbred cattle during the study (Table 2). This type of cattle is more productive compared to local cattle raised by women. The women were more empowered by earning more money from dairy farming through their choice of crossbred cattle.

Table 2. Distribution of factors affecting women's empowerment through small-scale dairy farming.

\begin{tabular}{|c|c|c|c|c|c|}
\hline \multirow{2}{*}{ Variable with category } & & \multicolumn{2}{|c|}{ Before study } & \multicolumn{2}{|c|}{ During study } \\
\hline & & Frequency & Percentage & Frequency & Percentage \\
\hline \multirow{2}{*}{ Types of breed were reared } & Local & 47 & 94 & 19 & 38 \\
\hline & Crossbred & 3 & 6 & 31 & 62 \\
\hline \multirow{3}{*}{ Husband's behavior } & Good & 4 & 8 & 33 & 66 \\
\hline & Moderate & 16 & 32 & 9 & 18 \\
\hline & $\mathrm{Bad}$ & 30 & 60 & 8 & 16 \\
\hline \multirow{2}{*}{$\begin{array}{l}\text { Reduce domestic } \\
\text { violence like physical } \\
\text { and mental abuse }\end{array}$} & Yes & 12 & 24 & 33 & 66 \\
\hline & No & 38 & 76 & 17 & 34 \\
\hline \multirow{2}{*}{ Reduce early marriage } & Yes & 11 & 22 & 36 & 72 \\
\hline & No & 39 & 78 & 14 & 28 \\
\hline \multirow{2}{*}{$\begin{array}{l}\text { Increase in knowledge and skill for } \\
\text { improving farm productivity }\end{array}$} & Yes & 15 & 30 & 37 & 74 \\
\hline & No & 35 & 70 & 13 & 26 \\
\hline \multirow{2}{*}{ Reduction of dependency } & Yes & 14 & 28 & 32 & 64 \\
\hline & No & 36 & 72 & 18 & 36 \\
\hline
\end{tabular}

Source: Field Survey

The husband's behavior was found statistically significant in women's empowerment (Table 2). In rural areas of Bangladesh, traditionally husbands do not allow their wives to participate in family or major household decisions. Rural women married to especially patriarchal and controlling husbands have been constrained in pursuing empowerment. More recently, however, traditional ways of thinking are changing among women. Women receive little respect from their husbands and the family-in-law may even consider the wife and her children as expense burdens on the husband, contributing to family conflict. It was observed from Table 2 that the majority of the selected rural women were $(66 \%)$ reporting good behavior from their husbands during the study while a higher percentage $(60 \%)$ of selected rural women reported bad behavior from their husbands before the study.

Women now have the right to spend the family income and make decisions independent of permission from their husband or other male members of the family. Particularly women's involvement in dairy farming is fostering a desire for independence. Their husbands are supportive of these efforts, recognizing the financial support the women can bring to the family. Therefore, rural women are being empowered through small-scale dairy farming and able to redefine their position in their family. The husbands' supportive behavior towards their wives is therefore an important factor for women's empowerment in selected study areas. The study evidence has also previously reported that when women are allowed to start and run their own business, their status in the family improves considerably (Islam et al., 2012). The breakdown of traditional socio-cultural norms was observed to be another important factor contributing to the greater empowerment of women. Before beginning dairy farming, the primary role of these women was as housewives and they had no independence.

According to Parveen and Leonhauser (2004), the most common forms of domestic violence against women at the hands of their husband or family include physical abuse, threats of divorce from the husband, unwillingness from the husband to provide family support, and mental abuse. All these can have a serious negative consequence on women's health and quality of life and prevent empowerment. Since participating in incomegenerating activities such as dairy farming, however, these women play a more active role in family finances and acquire some bargaining power within their family, thus diminishing the prior gender inequality and providing some protection against domestic violence.

The majority of the selected rural women (66\%) agreed that violence against them have been reduced (Table 2) by small-scale dairy farm activities. The women were also able to increase their mobility, develop more interpersonal interactions, and through exposure to the media (via television), are made more aware of illegal treatment at the hands of their husbands and may seek to demand their rights.

Early marriages could often lead to early motherhood and various health risks to mother and child. The prevalence of early marriage has now begun to decrease leading also to improved health among young women. 
This social and cultural progress has not been made before inclusion of SDF. The majority of the selected rural women $(60 \%)$ strongly agreed that early marriage was reduced by small-scale dairy farming.

Women's involvement in dairy farming is the increased awareness of education and in particular the importance of educating girls from a young age. Previously, early marriages were a predominant factor preventing the education of young girls and stalling any empowerment process (Hossain, 2011). Overall women in experienced an increase in knowledge and skill through small-scale dairy farming (Table 2). It was observed that $74 \%$ of the selected rural women increased their knowledge, skill and capability through dairy farming.

The income earned through dairy farming has reduced the dependency significantly of women in selected study areas during the study rather than before study. It was observed that $64 \%$ of the selected rural women in reduced their dependency through dairy farming (Table 2).

In addition to factors such as access to television and mobile phones, the selected area was situated near Bangladesh Agricultural University (BAU), and thus women are able to seek input from professors, veterinary surgeons, and Artificial Insemination (AI) center scientists to improve their farming ability.

\subsection{Awareness level of selected rural women}

Awareness is the ability to directly know and perceive, to feel, or to be cognizant of events. More broadly, it is the state of being conscious of something. Awareness is also associated with consciousness in the case this concept denotes a fundamental experience such as a feeling or intuition that accompanies the experience of phenomena.

Table 3. Comparison of awareness level of selected rural women before and during study.

\begin{tabular}{|c|c|c|c|c|}
\hline \multirow{2}{*}{\multicolumn{3}{|c|}{ Indicators with determinants }} & \multicolumn{2}{|c|}{ Frequency Percentage } \\
\hline & & & Before study & During study \\
\hline \multirow{6}{*}{ 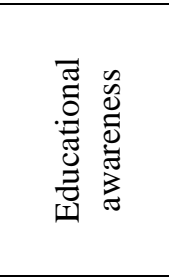 } & \multirow{2}{*}{ Taking decision in admitting their children in school } & Yes & 34 & 58 \\
\hline & & No & 66 & 38 \\
\hline & \multirow{2}{*}{ Taking decision to keep tutor for their children } & Yes & 18 & 64 \\
\hline & & No & 82 & 36 \\
\hline & \multirow{2}{*}{$\begin{array}{l}\text { Carefully monitoring the performance of their } \\
\text { children }\end{array}$} & Yes & 14 & 30 \\
\hline & & No & 86 & 70 \\
\hline \multirow{10}{*}{ 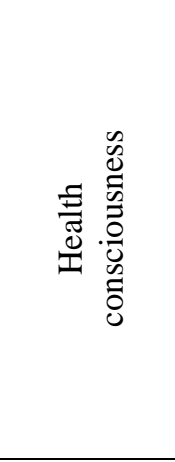 } & \multirow{2}{*}{$\begin{array}{l}\text { Decision making to visit hospital or clinic in face of } \\
\text { sickness, pregnancy or related health matter }\end{array}$} & Yes & 26 & 56 \\
\hline & & No & 74 & 44 \\
\hline & \multirow{2}{*}{ Choosing vaccination program for children } & Yes & 24 & 58 \\
\hline & & No & 76 & 42 \\
\hline & \multirow{2}{*}{ Participation in family planning } & Yes & 12 & 68 \\
\hline & & No & 88 & 52 \\
\hline & \multirow{2}{*}{$\begin{array}{l}\text { Opting better treatment for their children and also } \\
\text { family member }\end{array}$} & Yes & 16 & 72 \\
\hline & & No & 84 & 28 \\
\hline & \multirow{2}{*}{ Repeated pregnancy } & Yes & 14 & 62 \\
\hline & & No & 86 & 38 \\
\hline \multirow{8}{*}{ 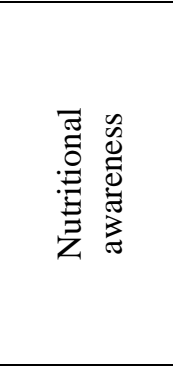 } & \multirow{2}{*}{ Making nutritious food choices for family } & Yes & 32 & 52 \\
\hline & & No & 68 & 48 \\
\hline & \multirow{2}{*}{ Avoidance of fast food } & Yes & 8 & 34 \\
\hline & & No & 92 & 66 \\
\hline & \multirow{2}{*}{ Making healthy daily food for family } & Yes & 32 & 50 \\
\hline & & No & 68 & 50 \\
\hline & \multirow{2}{*}{ Practicing one cup milk every day for every child } & Yes & 6 & 76 \\
\hline & & No & 94 & 24 \\
\hline \multirow{6}{*}{ 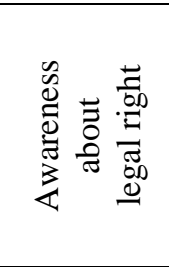 } & \multirow{2}{*}{ Lawful marriage age } & Yes & 24 & 54 \\
\hline & & No & 76 & 46 \\
\hline & \multirow{2}{*}{ Dowries } & Yes & 30 & 68 \\
\hline & & No & 70 & 32 \\
\hline & \multirow{2}{*}{ Divorce } & Yes & 34 & 78 \\
\hline & & No & 66 & 22 \\
\hline
\end{tabular}

Source: Field Survey 
This study measured that small-scale dairy farming significantly improved the awareness level of the respondent. The majority of the selected rural women agreed that they were more aware of education, health, nutrition, and legal right during the study period than the before inclusion of small-scales dairy farming.

In the rural area, the educational awareness was focused by taking decision in admitting their children in school, taking decision to keep tutor for their children and carefully monitoring the performance of their children. Nazneen et al. (2011) examined women's empowerment in post-independence Bangladesh and noted improvements in female education, treatment in health facilities, and participation in the labor force.

This study investigated that before inclusion of SDF, 34, 18, and 14 percent selected rural women agreed that they were aware of taking decision in admitting their children in school, taking decision to keep tutor for their children and carefully monitoring the performance of their children respectively. In contrast, 58, 64 and 30 percent selected rural women were aware of education during the study respectively (Table 3 ). The average educational awareness level of selected rural women was found as 22 percent before the study. Whereas, during the study, average educational awareness level of was found 50.66 percent. The findings of this study exhibited that through small-scale dairy farming, the selected women were more awareness regarding by taking decision in admitting their children in school, taking decision to keep tutor for their children and carefully monitoring the performance of their children than before the study.

The selected rural women of the study area were comparatively more conscious regarding their health during the study. The study shown that before inclusion of small-scale dairy farming, 26, 24, 12, 16 and 14 percent elected rural women agreed that they were aware of decision making to visit hospital or clinic in face of sickness, pregnancy or related health matter, choosing vaccination program for children, participation in family planning, opting better treatment for their children and also family member and repeated pregnancy respectively. In addition, 56, 58, 68, 72 and 62 percent selected rural women were conscious about their health during the study respectively (Table 3 ).

Despite strong biological evidence on the links between dairy consumption and child growth, and substantial empirical evidence from developed country populations, surprisingly little research has documented the impacts of regular consumption of dairy products on child growth in developing countries (Choudhury et al., 2018). The average health consciousness level of selected rural women was found as 18.4 percent before study. In contrast, during the study, average health consciousness level of was found 63.2 percent. This study shown that through small-scale farming activities women in rural area were significantly more conscious their health than before the study.

Nutritional awareness plays a significant role to improve the confidence level of women in rural area who are actively engaged with small-scale dairy farming activities. This study found that before inclusion of SDF, 32, 8 , 32 and 6 percent selected rural women agreed that they were aware of making nutritious food choices for family, avoidance of fast food, making healthy daily food for family and practicing one cup milk every day for every child respectively. Whereas, 52, 34, 50 and 76 percent selected rural women were aware of nutrition the study respectively (Table 3 ).

The average awareness level about nutrition of selected rural women was found as 19.5 percent before the study. In addition, during the study, average awareness level was found 53 percent. This study exhibited that through small-scale dairy farming, the selected women were more conscious about making nutritious food choices for family, avoidance of fast food, making healthy daily food for family and practicing one cup milk every day for every child respectively which contributed to build up their family healthy wealthy and sound.

The selected rural women of the study area were comparatively more aware of legal right like lawful marriage age, and divorce. The study exposed that before inclusion of small-scale dairy farming, 24, 30 and 34 percent selected rural women agreed that they were aware of marriage age, dowries and divorce respectively. In addition, 54, 68 and 78 percent selected rural women were aware of the legal right like lawful marriage age, and divorce during the study respectively (Table 3 ).

The average awareness level about legal right of selected rural women was found as 29.33 percent before study while during the study, average awareness level was found 66.33 percent. This study revealed that women were significantly more aware of legal right lawful marriage age, and divorce through small-scale farming activities in rural area.

\section{Conclusions}

The study illustrated the impact of small-scale dairy farming in rural area for the development and empowerment in rural women. In rural area of Bangladesh, the traditional role of women is to stay at home and look after children and house work according to their social standing and financial ability. The women in some selected areas of Mymensingh district in Bangladesh were empowered through small-scale dairy farming by 
increasing their socio-economic status and awareness about educational, health, nutritional, legal right such as early marriage, dowries and divorce, enabling women to participate in independent decision-making at the household and increased involvement in family affairs, increasing women access to and controlling of economic resources at the household and community level and also increasing their confidence level to enhance small-scale dairy farming in the society for poverty reduction. The greatest influencing factors affecting rural women's empowerment through small-scale dairy were the husband's behavior, successful reduction of the dependency of rural women, increase knowledge and skill, a breakdown of traditional socio-cultural norms and finally types of dairy breed (cross breed) raised significantly. The women's confidence level enhanced their efficiency and productivity in small-scale dairy farming which contributed to achieve ascent in their living standards and increased involvement in family affairs and community level.

\section{Conflict of interest}

None to declare.

\section{References}

Afzal A, T Ali, M Ahmad, MI Zafar, SK Niazi and F Riaz, 2009. Identification of factors hampering women empowerment in agricultural decision-making and extension work in district Okara, Punjab, Pakistan. Pak. J. Agric. Sci., 46: 64-68.

Ahmed F, C Siwar and NAH Idris, 2011. Contribution of rural women to family Income through participation in microcredit: An empirical analysis. Am. J. App. Sci., 8: 238-245.

Alhassan AR and MA Akudugu, 2012. Impact of microcredit on income generation capacity of women in the Tamale Metropolitan area of Ghana. Journal of Economics and Sustainable Development, 3: 41-48.

Awojobi ON, 2014. Empowering women through micro finance: Evidence from Nigeria. Australian Journal of Business and Management Research, 4: 17-26.

Banu D, F Farashuddin, A Hossain and S Akter, 2001. Empowering women in rural Bangladesh: Impact of Bangladesh Rural Advancement Committee's (BRAC's) Program. J. Int. Women Stud., 2: 30-53.

Batliwala S, 1994. The meaning of women's empowerment: New concepts from action. In Population policies reconsidered: Health, empowerment and rights. Harvard University, Harvard Center for Population and Development Studies, pp. 127-138.

Batool Z, HM Warriach, S Ishaq, M, Latif, MA Rashid, A Bhatti, N Murtaza, S Arif and PC Wynn, 2014. Participation of women in dairy farm practices under smallholder production system in Punjab, Pakistan. The Journal of Animal and Plant Sciences, 24: 1263-1265.

Bayeh E, 2016. The role of empowering women and achieving gender equality to the sustainable development of Ethiopia. Pacific Science Review B: Humanities and Social Sciences, 2: 38.

Choudhury S and DD Headey, 2018. Household dairy production and child growth: Evidence from Bangladesh. Econ. Hum. Biol., 30: 150-161.

Department of Livestock Services, 2018. Ministry of Fisheries and Livestock, Govt. of the People's Republic of Bangladesh. Livestock Economy 2017-18, 18: 42-44.

Haque MM, TM Islam, MI Tareque and MG Mostofa, 2011. Women empowerment or autonomy: A comparative view in Bangladesh context. Bangladesh e-Journal of Sociology, 8: 17-98.

Hashemi SM and SR Schuler, 1993. Defining and studying empowerment of women: A Research note from Bangladesh. JSI Working Paper No. 3. Washington DC: John Snow, Inc.

Hossain MA, 2011. Socio-economic obstacles of women empowerment in rural Bangladesh: A study on Puthiaupazila of Rajshahi district. Research on Humanities and Social Sciences, 1: 1-13.

Islam N, E Ahmed, J Chew and B D'Netto, 2012. Determinants of empowerment of rural women in Bangladesh. World J. Manag., 4: 36-56.

Islam MS, MF Ahmed and MS Alam, 2014. The role of microcredit program on women empowerment: Empirical evidence from rural Bangladesh. Developing Country Studies, 4: 90-97.

Kabeer N, 1999. Resources, agency, achievements: Reflections on the measurement of Women's empowerment. Development and Change, 30: 435-464.

Kamal S, 1995. Empowerment of women, Nairobi, 85 to Beijing, 95. Women for women. Bangladesh Population Research and Policy Review, 13: 257-273.

Keller B and DC Mbwewe, 1991. Policy and planning for the empowerment of Zambia's women farmers. Canadian Journal of Development Studies, 12: 75-88.

Kumar D, A Hossain and MC Gope, 2013. Role of microcredit program in empowering rural women in Bangladesh: A Study on Grameen Bank Bangladesh Limited. Asian Business Review, 3: 114-120. 
Mujahid N, M Ali, M Noman and M Begum, 2015. Dimensions of women empowerment: A case study of Pakistan. Journal of Economics and Sustainable Development, 6: 37-45.

Mulugeta M and T Amsalu, 2014. Women's role and their decision making in livestock and household management. Journal of Agricultural Extension and Rural Development, 6: 347-353.

Nazneen S, N Hossain and M Sultan, 2011. National discourses on women's empowerment in Bangladesh: Continuities and change. Institute of Development Studies, pp. 368.

Nessa T, J Ali and AR Hakim, 2012. The impact of microcredit programs on women empowerment: Evidence from Bangladesh. OIDA International Journal of Sustainable Development, 3: 11-20.

Oso WY and D Onen, 2005. A general guide to writing research proposal and report: A handbook for Beginning researchers Kisumu: Options Press and Publishers.

Parveen S and IU Leonhauser, 2004. Empowerment of rural women in Bangladesh: A household level analysis. Conference on rural poverty reduction through research for development transformation, Deutscher Tropentag-Berlin, 5-7 October.

Parveen S and MR Chaudhury, 2009. Microcredit intervention and its effects on empowerment of rural women: The BRAC experience. Bangladesh Research Publications Journal, 2: 641-647.

Sarah Y and Y Ikemoto, 2015. Women's participation in small-scale dairy farming for poverty reduction in Bangladesh. Am. Int. J. Soc. Sci., 4: 21-33.

Siddique MAB, 1998. Gender issues in poverty alleviation: A case study of Bangladesh. Int. J. Soc. Eco., 25:1095-1112.

Sultana AM, 2010. Cultural dimensions of women's discriminations in rural communities. Oz. J. Soc. Sci., 3: 31-38.

Uddin MN, MB Uddin, M Al Mamun, MM Hassan and MMH Khan, 2012. Small scale dairy farming for livelihoods of rural farmers: constraint and prospect in Bangladesh. J. Anim. Sci. Adv., 2: 543-550. 